\title{
An appraisal of third complement component (C3) and breakdown product (C3d) in erythema nodosum leprosum (ENL)
}

\author{
K SAHA $^{1}$, A K CHAKRABORTY ${ }^{2}$, VINAY SHARMA ${ }^{3}$ \\ and $\mathrm{V} \mathrm{N} \mathrm{SEHGAL}{ }^{4}$ \\ ${ }^{1}$ Associate Professor, Department of Bacteriology, Gobind \\ Ballabh Pant Hospital, New Delhi; ${ }^{2}$ Reader, Department of \\ Biochemistry, University College of Medical Sciences, New \\ Delhi; ${ }^{3}$ Lecturer, Department of Microbiology, Maulana Azad \\ Medical College, New Delhi; ${ }^{4}$ Professor and Head, Department \\ of Dermatology and Venereology, Maulana Azad Medical College \\ and associated L.N.J.P.N. \& G.B. Pant Hospital, New Delhi
}

\section{Received for publication 11 January 1982}

\begin{abstract}
Summary Sera from 20 patients with erythema nodosum leprosum (ENL) were collected at the first visit, and 4 weeks after successful therapy. The levels of $\mathrm{C} 3, \mathrm{C} 3 \mathrm{~d}, \mathrm{C} 1 \mathrm{q}$ and $\mathrm{C} 4$ were measured in 20 paired samples. Acute phase reactants - alpha-1-antitrypsin (AAT), alpha-2-macroglobulin (AMG) and C-reactive protein (CRP) - were also estimated to monitor the activity of ENL. The mean serum C3 level showed a decrease during ENL, while after remission it showed a significant increase. Even then, the $\mathrm{C} 3$ level after remission was less than that in healthy controls. The mean level of $\mathrm{C} 3 \mathrm{~d}$ increased remarkably during ENL, and this increase persisted in most patients even after the clinical remission. An inverse relationship between $\mathrm{C} 3 \mathrm{~d}$ and $\mathrm{C} 3$ suggests that the determination of $\mathrm{C} 3 \mathrm{~d}$ forms a better indicator of C3 hypercatabolism during ENL. Clofazimine treatment resulted in a remarkable decrease of $\mathrm{C} 3 \mathrm{~d}$, in contrast to those treated with prednisolone and chloroquine. Mean levels of AAT were greatly elevated during ENL but decreased significantly after its clinical remission.

Serum levels of $\mathrm{C} 1 \mathrm{q}, \mathrm{C} 4, \mathrm{AMG}$ and CRP did not alter significantly during ENL and also showed no difference in patients on ENL therapy.
\end{abstract}

\section{Introduction}

Erythema nodosum leprosum (ENL) and its association with circulating and tissue deposited immune complexes have been amply demonstrated. ${ }^{1,2}$ A few studies have also been made to demonstrate changes in the serum levels of complement components in both lepromatous leprosy and ENL, ${ }^{3,4}$ but followup studies amongst these patients have not been adequately reported in the 
literature. Also, very recently, the levels of $\mathrm{C} 3 \mathrm{~d}$ and $\mathrm{Ba}$, breakdown products of C3 and factor B respectively have been correlated with the clinical manifestations of lepromatous leprosy., ${ }^{1,5}$ This report deals with the studies of complement components $(\mathrm{Cl} \mathrm{q}, \mathrm{C} 4$ and $\mathrm{C} 3)$ and its breakdown product $(\mathrm{C} 3 \mathrm{~d})$ in 20 patients during and after ENL. We have also monitored the effect of ENL on serum concentrations of acute phase reactants, namely, alpha-1-antitrypsin (AAT), alpha-2-macroglobulin (AMG) and C-reactive protein (CRP).

\section{Materials and methods}

Human materials and their clinical profile. Twenty adult patients (mean age 32.6 years, range $22-50$ years) attending the Urban Leprosy Centre, National Leprosy Control Programme, Department of Dermatology and Venereology, Safdarjang Hospital, New Delhi, were studied. The diagnosis of leprosy was established in each case according to published criteria. ${ }^{6}$ Eight of the 20 patients belonged to borderline (BL) and 12 to lepromatous (LL) leprosy. Duration of illness varied from 2 years to 18 years with a mean of 4.5 years. The diagnosis of ENL in these patients was made on well-formed clinical features. ${ }^{7}$ In 9 patients the ENL was recorded for the first time, while in the rest of the patients there had been one to three episodes of recurrence and remission. Prednisolone was administered in 11, clofazimine in 3 and chloroquine in 6 patients in recommended dose schedule. ${ }^{8}$

Two samples of $5 \mathrm{ml}$ venous blood were collected from each patient. The initial sample was collected on the first visit, while the subsequent sample was drawn on clinical remission of ENL 4 weeks later. Sera were separated and stored in small aliquots at $-20^{\circ} \mathrm{C}$. Sera were also obtained from 15 properly matched controls.

Immunological techniques. Complement components $\mathrm{C} 1 \mathrm{q}, \mathrm{C} 3$ and $\mathrm{C} 4$ as well as acute phase reactants, namely, AAT, AMG and CRP, were estimated in the serum samples by single radial immunodiffusion technique ${ }^{9}$ using monospecific antisera and reference standards. Anti-Clq antiserum was obtained from Behring Institute, West Germany. Anti-CRP antiserum was procured from Kallestad Laboratory, USA, while remaining antisera (against C3, C4, AAT, $\mathrm{AMG}$ ) and their reference standards were procured from Meloy Laboratories, USA. The levels of $\mathrm{C} 3$ and $\mathrm{C} 4$ as well as AAT and AMG were expressed as $\mathrm{mg} / \mathrm{dl}$ of serum. The concentrations of $\mathrm{Clq}$ and CRP in the samples were compared with the WHO reference standard serum 67/97 and a locally obtained serum containing a high titre of C-reactive protein respectively. These were expressed in units/dl taking the abovementioned standard sera as 100 units/dl. For quantitation of $\mathrm{C} 3 \mathrm{~d}$ fragment a two-step immunochemical procedure was used. ${ }^{10}$ In brief, $0.2 \mathrm{ml}$ of serum samples were mixed with $0.2 \mathrm{ml}$ of polyethylene glycol 6000 (PEG, BDH, England; final concentration 11\%). The 
mixture was left at $4{ }^{\circ} \mathrm{C}$ for $3 \mathrm{hr}$ and then centrifuged for $30 \mathrm{~min}$ at $1200 \mathrm{~g}$ to precipitate native $\mathrm{C} 3$ and $\mathrm{C} 3 \mathrm{~b}$. With $\mathrm{D}$ antigen-specific antiserum (Central Laboratory, Amsterdam), the concentration of $\mathrm{C} 3 \mathrm{~d}$ was measured in the supernatant by radial immunodiffusion. The standard reference curve was obtained with pooled fresh sera previously activated with insulin $(2 \mathrm{mg} / \mathrm{ml})$ for $1 \mathrm{hr}$ at $37^{\circ} \mathrm{C}$ and then treated with PEG (final concentration $11 \%$ ). The C3d levels in the test sera were expressed as units/dl taking pooled serum control as 100 units/dl.

The data were analysed and evaluated statistically using paired $t$-test.

\section{Observations}

Mean serum levels of the complement components $(\mathrm{Clq}, \mathrm{C} 3, \mathrm{C} 4)$ and $\mathrm{C} 3 \mathrm{~d}$ during ENL and after its subsidence are shown in Table 1. Increased catabolism of $\mathrm{C} 3$, the key substance of the complement system, during the episode was evident by the significantly low levels of $\mathrm{C} 3$ as compared to healthy controls. Furthermore, there was a four-fold increase in the ratio of C3d to C3 (Table 1), and a negative relationship between $\mathrm{C} 3$ and $\mathrm{C} 3 \mathrm{~d}$ levels $(r=-0.36$, Fig. 1$)$. In contrast, $\mathrm{Clq}$ and $\mathrm{C} 4$ levels did not show any variation during ENL.

The levels of acute phase reactants during and after ENL are given in Table 2. The mean level of AAT was very high during the episode and it showed a statistically significant decrease $(23 \%$ fall, $t=2.55, p<0.05)$ a month later. The mean levels of AMG and CRP, on the other hand, did not vary appreciably in the paired samples.

Table 1. Profile of complement components and $\mathrm{C} 3$ breakdown product, $\mathrm{C} 3 \mathrm{~d}$ in healthy subjects and in lepromatous patients during erythema nodosum leprosum and after remission.

\begin{tabular}{|c|c|c|c|}
\hline \multirow{3}{*}{$\begin{array}{l}\text { Complement } \\
\text { components }\end{array}$} & \multicolumn{3}{|c|}{ Serum concentration* (mean \pm S.D. $($ range $)$} \\
\hline & \multirow[t]{2}{*}{ Healthy subjects } & \multicolumn{2}{|c|}{ Erythema nodosum leprosum } \\
\hline & & During & After remission \\
\hline $\mathrm{C} 3$ & $211 \pm 38(101-300)$ & $97 \pm 23(70-150)^{\dagger}$ & $116 \pm 25(70-170)^{\dagger}$ \\
\hline $\mathrm{C} 3 \mathrm{~d}$ & $63.5 \pm 35(75-127)$ & $132 \pm 74(28-285)^{\ddagger}$ & $135 \pm 75(33-264) \ddagger$ \\
\hline $\mathrm{Clq}$ & $137 \pm 48(75-215)$ & $153 \pm 64(65-300) \ddagger$ & $168 \pm 46(88-280)^{\ddagger}$ \\
\hline $\mathrm{C} 4$ & $31 \pm 10(20-57)$ & $33 \pm 10(12-55)^{\ddagger}$ & $36 \pm 12(12-70)^{\ddagger}$ \\
\hline Ratio of $\mathrm{C} 3 \mathrm{~d}: \mathrm{C} 3$ & 0.30 & 1.33 & 1.32 \\
\hline
\end{tabular}

*Serum concentrations of $\mathrm{C} 3$ and $\mathrm{C} 4$ were expressed as $\mathrm{mg} / \mathrm{dl}$, those of $\mathrm{C} 3 \mathrm{~d}$ and $\mathrm{C} 1 \mathrm{q}$ as units/dl.

$\dagger$ Difference statistically significant $(p<0.05)$.

$¥$ Differences statistically not significant. 


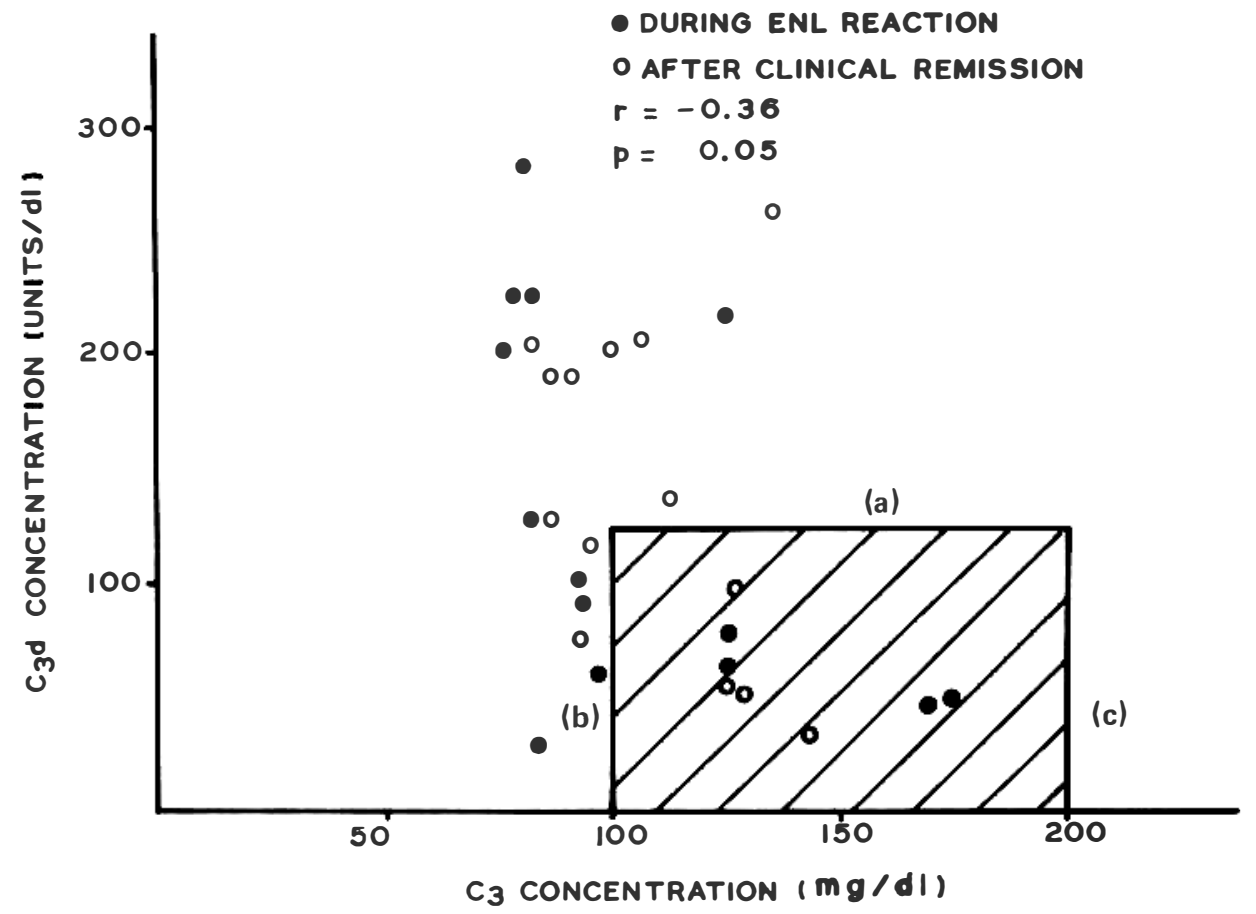

Figure 1. Inverse relationship between serum concentrations of complement component C3 and its breakdown product, C3d during ENL and after clinical remission. Shaded area indicates (a) normal upper limit of $\mathrm{C} 3 \mathrm{~d}$ level, (b) normal lower limit of $\mathrm{C} 3$ level in sera from healthy subjects, (c) mean $\mathrm{C} 3$ level in sera from healthy subjects.

Table 2. Profile of acute phase reactants in healthy subjects and in lepromatous patients during ery thema nodosum leprosum and after its remission.

\begin{tabular}{|c|c|c|c|}
\hline \multirow{3}{*}{$\begin{array}{l}\text { Acute phase } \\
\text { reactants }\end{array}$} & \multicolumn{3}{|c|}{ Serum concentration* $($ mean \pm S.D. (range) } \\
\hline & \multirow[t]{2}{*}{ Healthy subjects (15) } & \multicolumn{2}{|c|}{ Erythema nodosum leprosum (20) } \\
\hline & & During & Af ter remission \\
\hline $\begin{array}{l}\text { Alpha-1- } \\
\text { antitrypsin } \\
\text { (AAT) }\end{array}$ & $225 \pm 85(35-290)$ & $434 \pm 125(210-600)^{\dagger}$ & $334 \pm 123(180-590)^{\dagger}$ \\
\hline $\begin{array}{l}\text { Alpha-2- } \\
\text { macroglobulin } \\
\text { (AMG) }\end{array}$ & $284 \pm 89(150-335)$ & $283 \pm 100(105-475)^{\ddagger}$ & $249 \pm 100(95-430) \ddagger$ \\
\hline $\begin{array}{l}\text { C-reactive } \\
\text { protein }(\mathrm{CRP})\end{array}$ & Not detected & $38 \pm 34 \quad(0-100) \ddagger$ & $37 \pm 42(0-125)^{\ddagger}$ \\
\hline
\end{tabular}

* Serum concentrations of AAT and AMG were expressed as $\mathrm{mg} / \mathrm{dl}$, those of CRP as units/dl.

$\dagger$ Difference statistically significant $(p<0.05)$.

$\ddagger$ Difference statistically not significant. 
Table 3. Correlation of the profile of acute phase reactants, complement system and clinical picture with three drugs used in the therapy of ery thema nodosum leprosum.

\begin{tabular}{|c|c|c|c|c|c|c|}
\hline \multirow[b]{3}{*}{ Drug } & \multirow[b]{3}{*}{$\begin{array}{l}\text { Patients } \\
\quad(n)\end{array}$} & & & \multicolumn{3}{|c|}{$\begin{array}{l}\text { Changes in sera following } \\
\text { clinical remission of ENL }\end{array}$} \\
\hline & & \multicolumn{2}{|c|}{$\begin{array}{c}\text { Clinical remission } \\
\text { of ENL }\end{array}$} & \multirow{2}{*}{$\begin{array}{c}\text { Acute phase } \\
\text { reactant } \\
\% \text { Decrease of } \\
\text { alpha-1- } \\
\text { antitrypsin }\end{array}$} & \multicolumn{2}{|c|}{$\begin{array}{l}\text { Complement and its } \\
\text { breakdown product }\end{array}$} \\
\hline & & (week) & $(n)$ & & $\begin{array}{c}\% \text { Increase of } \\
\text { serum C3 } \\
\text { level }\end{array}$ & $\begin{array}{c}\% \text { Change in } \\
\text { serum C3d } \mathrm{d}^{\dagger} \\
\text { level }\end{array}$ \\
\hline Prednisolone & 11 & $\begin{array}{l}1 \mathrm{st} \\
2 \mathrm{nd}\end{array}$ & $\begin{array}{l}6 \\
5^{*}\end{array}$ & 11 & 17 & 20 (rise) \\
\hline Chloroquine & 6 & $\begin{array}{l}1 \mathrm{st} \\
2 \mathrm{nd}\end{array}$ & $\begin{array}{l}3 \\
3 *\end{array}$ & 43 & 13 & 42 (rise) \\
\hline Clofazimine & 3 & $1 \mathrm{st}$ & 3 & 32 & 22 & 70 (fall) \\
\hline
\end{tabular}

*One patient in each group showed only partial clinical relief.

$\dagger \mathrm{C} 3 \mathrm{~d}$ levels were estimated in 8 cases on prednisolone, 3 cases on chloroquine and 3 cases on clofazimine therapy.

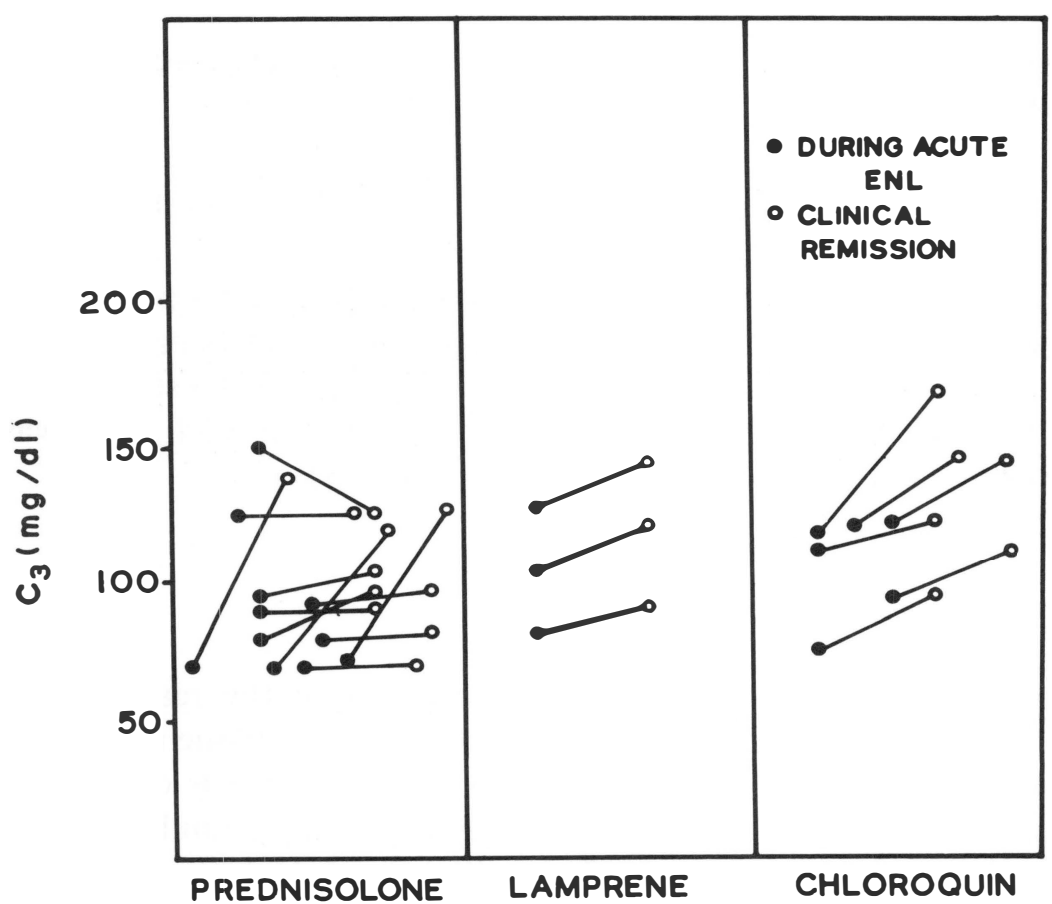

Figure 2. Effect of different drugs used in ENL on the serum concentration of complement component $\mathrm{C} 3$ in patients with ENL. 


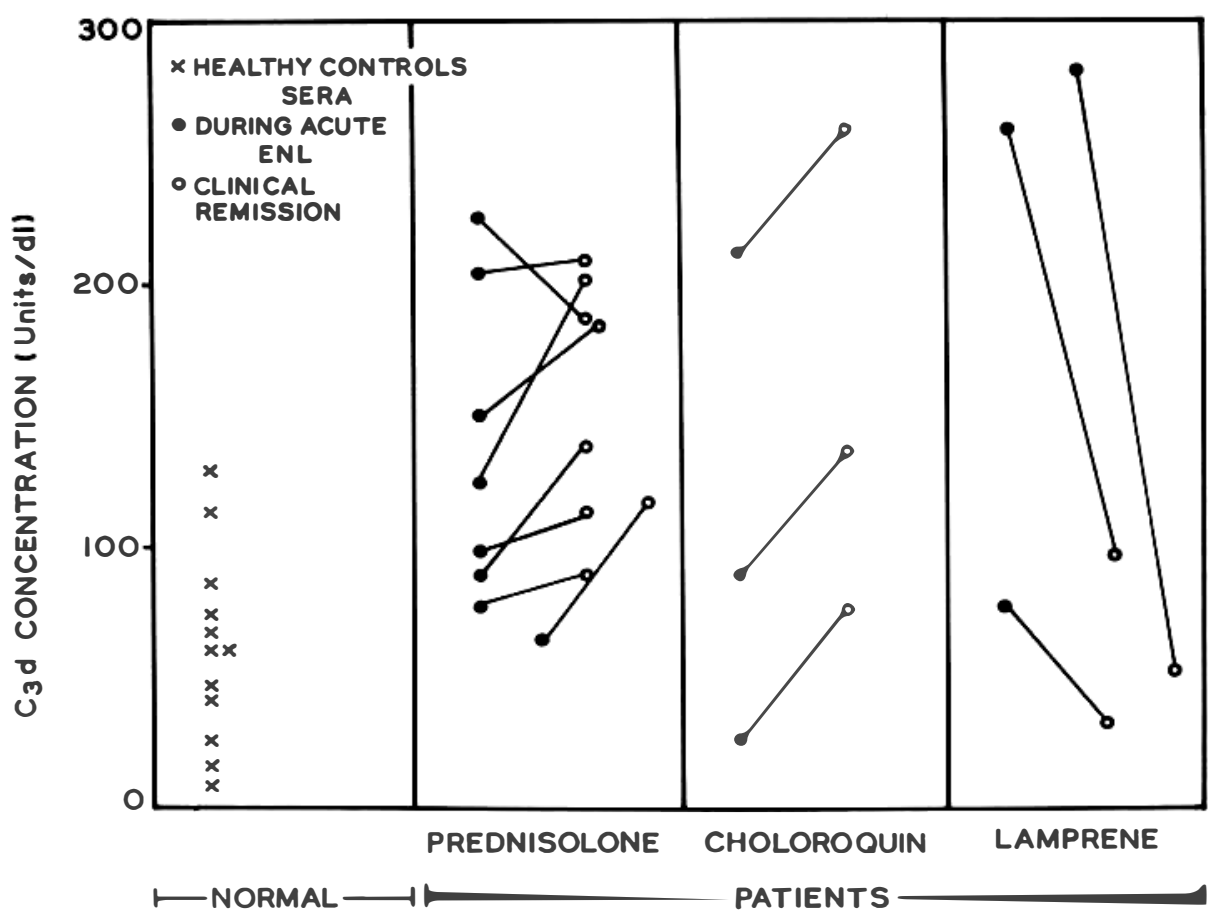

Figure 3. Effect of different drugs used in ENL on the serum concentration of $\mathrm{C} 3 \mathrm{~d}$ in patients with ENL.

The results of the drugs used in ENL and their effect on the profile of complement and acute phase reactants, are depicted in Table 3. It is apparent that the complement component $\mathrm{C} 3$ showed an increased concentration after recovery from ENL in all the treated groups, the effect being marked in those on clof azimine (Fig. 2). Similarly, the effect of drugs on the serum C3d concentration is shown in Fig. 3. Further, a significant fall in AAT levels was noticed in patients on chloroquine and clofazimine (Table 3).

\section{Discussion}

Activation of the complement system occurring in the reactionary form of leprosy amplifies inflammatory reaction and enhances tissue damage. This is an important feature of the ENL reaction. ${ }^{1,5,11}$ Normal levels of C1q, C3 and C4 in healthy adults from the same socio-economic background as the patients of present series were $137 \pm 48$ units, $211 \pm 38 \mathrm{mg}$ and $31 \pm 10 \mathrm{mg}$ per dl of serum respectively. The mean concentration of $\mathrm{C} 3$ component was significantly lower in the sera of our patients collected during the reactionary phase than in samples collected after clinical remission 4 weeks later, whereas the levels of $\mathrm{Clq}$ and 
C4 components varied only marginally (Table 1). Furthermore the decrease in C3 levels in comparison to the normal levels $(211 \mathrm{mg} / \mathrm{dl})$ was striking both during ENL $(97 \pm 23 \mathrm{mg} / \mathrm{dl})$ and after clinical cure $(116 \pm 25 \mathrm{mg} / \mathrm{dl})$. Many attempts have been made to demonstrate changes in serum complement levels in ENL. 1, 3,4,5 Srivastava $^{4}$ showed a significant reduction of $\mathrm{C} 3$ component with normal $\mathrm{C} 4$ level in these patients, indicating involvement of the alternative pathway of complement activation. Bjorvatn et al. ${ }^{1}$ demonstrated increased level of the $\mathrm{C} 3$ breakdown product, $\mathrm{C} 3 \mathrm{~d}$ in the plasma of $70 \%$ of patients with ENL and in only $18 \%$ of patients without reaction. Saha \& Chakraborty ${ }^{5}$ also suggested the activation of complement by the alternative pathway in ENL patients, for they had observed a significant rise of $\mathrm{Ba}$, the breakdown product of factor B in the presence of a fall of C3 level. In another study ${ }^{3}$ a fall in complement levels (CH50 and $\mathrm{C} 3$ ) was noticed during the third and fourth months in lepromatous patients with significant proteinuria, whereas $\mathrm{C} 4$ levels were normal. These earlier studies and the present one reinforce the view that complement activation during ENL occurs mostly through the alternative pathway. Furthermore, the correlation coefficient $r(\mathrm{C} 3 \mathrm{~d} v s \mathrm{C} 3)$ in our patients was similar to that observed in a study involving patients with membranoproliferative glomerulonephritis, ${ }^{10}$ where it was suggested that the detection of breakdown products of $\mathrm{C} 3$ gives a fair index of complement system involvement.

The assessment of $\mathrm{C} 3$ level appears significant in evaluating immune complex deposits. This view is supported by the observed deposition of $\mathrm{C} 3$ components in various parts of the body namely, the dermis, testes, peripheral nerves glomerular and tubular basement membranes of the kidney in ENL (unpublished data).

The C3 level after remission of ENL rose, ranging from 13 to $22 \%$ during therapy (Table 3). The levels of early complement components, $\mathrm{Clq}$ and $\mathrm{C} 4$ remained unaltered. Clofazimine appeared to decrease the level of $\mathrm{C} 3 \mathrm{~d}$, a breakdown product of $\mathrm{C} 3$, suggesting that this drug probably interferes with the breakdown of $\mathrm{C} 3$ and eliminates $\mathrm{C} 3 \mathrm{~d}$ from the circulation, while the situation is reversed with prednisolone and chloroquine.

The monitoring of acute phase reactants revealed a considerable elevation of serum AAT levels in the early phase of ENL, followed by a significant fall 4 weeks later. These observations are in keeping with those reported earlier. ${ }^{12}$ Further, it is believed that AAT is released during the active phase of leprosy, and that it counteracts various endogenous as well as exogenous proteases. ${ }^{13}$ It is interesting to note that AAT levels were markedly elevated in the early phase of ENL, but showed a significant decrease following remission. In patients treated with chloroquine and clofazimine this decrease was greater than in those on prednisolone (Table 3). The mean level of AMG, which also binds trypsin, plasmin and thrombin, remained unaltered in ENL, while it showed a considerable fall after remission (Table 2). It is believed that AMG participates in acute phase reactions. ${ }^{14} \mathrm{CRP}$ is another important acute phase reactant present in all 
types of leprosy, but is highly positive (97\%) in ENL. ${ }^{4,15}$ Our study demonstrated its presence in all paired samples though its concentration did not show a significant decline after subsidence of ENL. It is now known that $\mathrm{C}$-reactive protein is a precursor for protein $\mathrm{P}$, a minor component of all amyloid. ${ }^{16}$

\section{References}

1 Bjorvatn B, Barnetson FS, Kronvall GK, Zubler RH, Lambert PH. Immune complexes and complement hypercatabolism in patients with leprosy. Clin exp Immunol, 1976; 26: 388-96.

${ }^{2}$ Wemambu SNC, Turk JL, Waters MFR, Rees RJW. ENL - A clinical manifestation of the Arthus phenomenon. Lancet, 1969; ii: 933-5.

${ }^{3}$ Kumar B, Ganguly NK, Kaur S, Sharma S, Chakravarty RN, Mahajan RC. Complement profile in leprosy. Leprosy in India, 1980; 52: 217-22.

${ }^{4}$ Srivastava LM, Agarwal DP, Goldee HW, Rohde R. Biochemical, immunological and genetic studies in leprosy. II. Profile of immunoglobulins, complement components and C-reactive protein in sera of leprosy patients and healthy controls. Tropen Med Parasit, 1975; 26: 212-18.

5 Saha K, Chakraborty AK. Serum complement profiles in human leprosy and its comparison with immune complex diseases. Int J Lepr, 1977; 4 5: 327-37.

${ }^{6}$ Ridley DS, Jopling WH. Classification of leprosy according to immunity. Int J Lepr, 1966; 34: $255-73$.

7 Sehgal VN, Rege VL, Masuarruhans MF. Pattern of reactions in leprosy. A clinical appraisal. Lepr India, 1977; 49: 221-8.

8 Sehgal VN. Clinical leprosy. 1st ed. Sahibabad (UP): Vikas, 1979; 52-8.

9 Mancini G, Carbonara AC, Heremans JP. Immunochemical quantitation of antigens by single radial immuno-diffusion. Immunochemistry, 1965; 2: 235-54.

10 Perrin LH, Lambert PH, Miescher PA. Complement breakdown products in plasma from patients with systemic lupus erythematosus and in patients with membranoproliferative and other glomerulonephritis. J Clin Invest, 1975; 56: 165-76.

11 Bullock WE. Leprosy: A model of immunological perturbation in chronic infection. $J$ Inf Dis, 1978; 137: 341-54.

12 Agarwal SK, Saha K. Serum alpha-1-antitrypsin in various forms of leprosy. Indian Jour Med Res, 1978; 68: 136-9.

13 Hermann G, Miescher PA. Differentiation of leucocy tic fibrinolytic enzymes from plasmin by the use of plasmatic proteolytic inhibitors. Int Arch Allergy, 1965; 27: 346-54.

14 Housley J. Alpha-2-macroglobulin levels in diseases in man. J Clin Path, 1968; 21: 71822.

15 Sen Gupta U, Sinha S, Ramu G. Immunological assessment of sera of leprosy patients. Leprosy in India, 1979; 51: 43-8.

16 Sell S. Immunology, immunopathology and immunity. 3rd ed. Harper \& Row: 276. 1980. 